\title{
Sheehan's syndrome presenting with type III hyperlipoproteinaemia
}

\author{
David Carr, Heather M. Thornes, Alan C. Rutter, Roger D. Finney and \\ Peter R. Turner ${ }^{1}$
}

North Tees General Hospital, Hardwick, Stockton-on-Tees, Cleveland, TS19 8PE and 'Department of Chemical Pathology and Metabolic Disorders, St. Thomas' Hospital, London SE1, UK.

\begin{abstract}
Summary: A patient is described in whom the presenting feature of hypopituitarism was the development of palmar xanthomata associated with type III hyperlipoproteinaemia. Treatment of her secondary hypothyroidism with thyroxine caused resolution of the xanthomata and hyperlipidaemia, but the underlying compositional abnormality of the lipoproteins could still be observed.
\end{abstract}

\section{Introduction}

Type III hyperlipoproteinaemia (dysbetalipoproteinaemia, broad- $\beta$-disease) is an uncommon error of lipid metabolism, characterized by the presence of abnormal very low density and intermediate density lipoprotein (VLDL and IDL) particles with a high cholesterol to triglyceride ratio. ${ }^{1,2}$ Palmar and tuberous xanthomata are commonly found in patients with this disorder. Diagnosis of the type III hyperlipoproteinaemia genotype depends on showing presence of the apoprotein-E2 component in VLDL. While the genotype E2/E2 occurs in about $1 \%$ of the general population, its phenotypic expression is much rarer, and is usually associated with other problems such as obesity, hypothyroidism, diabetes mellitus or a coexistent separate familial hyperlipidaemia. We report a patient whose presenting features of hypopituitarism were palmar $\mathbf{x}$ anthomata associated with type III hyperlipoproteinaemia.

\section{Case report}

A Caucasian female aged 33 years presented with orange plaques in the creases of her palms for one year. On specific enquiry she also admitted to tiredness, cold intolerance, slowed speech, dry skin and reduced axillary hair. Eight years previously she had suffered a severe post-partum haemorrhage requiring blood transfusion. For four years afterwards she took oral contraceptives, following which she had insertion of an intra-uterine contraceptive device. Her periods then became lighter and infrequent, with amenorrhoea

Correspondence: D. Carr M.A., M.B., F.R.C.P.

Accepted: 16 July 1987 for up to 6 months. Examination revealed a slim woman with xanthomatous deposits in the skin creases of her palms, below the breasts and in the groins, and there was a small yellow cutaneous nodule on the extensor surface of her left elbow. Her serum cholesterol level was $14.8 \mathrm{mmol} / \mathrm{l}$, haemoglobin $10.8 \mathrm{~g} / \mathrm{dl}$, white cell count $4.8 \times 10^{9} / 1$ with neutropenia $\left(1.6 \times 10^{9} / 1\right)$, serum total thyroxine $14 \mathrm{nmol} / 1$ (normal 50-160), serum thyrotrophin (TSH) $3.5 \mathrm{mU} / 1$ (nor$\mathrm{mal}<6$ ), serum tri-iodothyronine $0.4 \mathrm{nmol} / 1$ (normal $1.2-3.0$ ), serum thyroxine binding globulin $19.1 \mathrm{mg} / 1$ (normal 7-17), immunofluorescent screen for thyroid microsomal antibodies was weakly positive. Urinalysis showed no glycosuria.

She was started on oral L-thyroxine $50 \mu \mathrm{g} /$ day following which she felt much better, with more energy, and resolution of the xanthomata. Four months later she underwent further investigations, including a skull X-ray which showed no abnormality of the pituitary fossa. Basal serum hormone measurements were: growth hormone $0.2 \mathrm{mU} / 1$, cortisol $105 \mathrm{nmol} / 1$, prolactin less than $100 \mathrm{mU} / 1$, TSH $3.3 \mathrm{mU} / 1$, follicle stimulating hormone $8.0 \mathrm{U} / 1$ and luteinising hormone $5.4 \mathrm{U} / 1$. Following a combined intravenous injection of insulin $(0.15 \mathrm{U} / \mathrm{kg})$, thyrotrophin releasing hormone $(200 \mu \mathrm{g})$ and gonadotrophin releasing hormone $(100 \mu \mathrm{g})$, her blood glucose fell to $1.0 \mathrm{mmol} / \mathrm{l}$ and peak serum hormone levels were: growth hormone $1.3 \mathrm{mU} / 1$, cortisol $146 \mathrm{nmol} / 1$, TSH $4.9 \mathrm{mU} / 1$, follicle stimulating hormone $9.9 \mathrm{U} / 1$ and luteinising hormone $11.5 \mathrm{U} / 1$, a response indicative of hypopituitarism.

Replacement therapy with hydrocortisone $(30 \mathrm{mg} /$ day) and increased L-thyroxine dosage $(150 \mu \mathrm{g} / \mathrm{day})$ was instituted. Serum lipid levels and the haemoglobin 
concentration returned to normal.

Two years later she remained well with sparse infrequent periods and no xanthomata, and while taking hydrocortisone and thyroxine further lipid studies were undertaken, showing serum cholesterol $6.7 \mathrm{mmol} / 1$, VLDL cholesterol $1.75 \mathrm{mmol} / 1$, IDL and low density lipoprotein cholesterol $3.8 \mathrm{mmol} / 1$, high density lipoprotein cholesterol $1.15 \mathrm{mmol} / \mathrm{l}$, serum triglyceride $2.71 \mathrm{mmol} / \mathrm{l}$, VLDL triglyceride $1.73 \mathrm{mmol} / 1$. The VLDL cholesterol: triglyceride ratio was 1.01 (normal $<0.8$ ) and the apo $\mathrm{E}$ phenotype was E2/E2.

\section{Discussion}

This woman presented with xanthomata and raised serum cholesterol typical of Fredrickson type III hyperlipoproteinaemia. ${ }^{1}$ Endocrine investigations demonstrated hypopituitarism with deficiencies of cortisol and growth hormone, and secondary hypothyroidism. Coupled with the obstetric and menstrual history this suggested the diagnosis of Sheehan's syndrome. Subsequently, demonstration of the raised VLDL cholesterol: triglyceride ratio ${ }^{2}$ and the apo E phenotype $^{3}$ confirmed the diagnosis of type III hyperlipoproteinaemia. Thyroxine therapy cleared the xanthomata and reduced the serum cholesterol towards normal (95th percentile for 20-39 year old females $=6.1 \mathrm{mmol} / \mathrm{l}$ ) although VLDL remained

\section{References}

1. Beaumont, J.L., Carson, L.A., Cooper, G.R., Fejfar, Z., Fredrickson, D.S. \& Strasser, T. Classification of hyperlipidaemias and hyperlipoproteinaemias. Bull WHO 1970, 43: 891.

2. Hazzard, W.R., Porte, D., Jr. \& Bierman, E.L. Abnormal lipid composition of very low density lipoprotein in diagnosis of broad-beta disease (type III hyperlipoproteinaemia). Metabolism 1972, 21: 1009-1019.

3. Utermann, G., Hees, M. \& Steinmetz, A. Polymorphism of apolipoprotein $\mathrm{E}$ and occurrence of dysbetalipoproteinaemia in man. Nature 1977, 269: 604-607.

4. Turner, P.R., Cortese, C., Wooton, R., Marenah, C., Miller, N.E. \& Lewis, B. Plasma apolipoprotein B abnormally cholesterol enriched. A probable mechanism for the beneficial reduction in cholesterol levels is the reduced synthesis of the endogenous VLDL, while the abnormal catabolism resulting from the lipoprotein receptors' non-recognition of the E2 apoprotein is unchanged with therapy. ${ }^{4}$

Expression of type III hyperlipoproteinaemia is well recognized in primary hypothyroidism. ${ }^{5}$ Previous studies of patients with hypopituitarism of various aetiologies include cases with hyperlipidaemia, although these reports antedated the recognition of the type III disorder as a discrete entity ${ }^{6,7}$ A more recent series of hyperlipidaemic patients with Sheehan's syndrome ${ }^{8}$ included 3 patients whose lipoprotein electrophoresis resembled the broad-beta type. There are no previous accounts of patients whose hypopituitarism presented primarily with clinical manifestations of type III hyperlipoproteinaemia. Our patient is, we believe, the first reported case to have palmar xanthomata as the presenting symptom of Sheehan's syndrome, with confirmation of the type III hyperlipoproteinaemia on the basis of the Apo E phenotype.

\section{Acknowledgements}

We are grateful to Dr G. Tildersley for referring this patient and to the Supra-regional Assay Service for measurement of prolactin, growth hormone, follicle stimulating hormone and ${ }^{\circ}$ luteinising hormone.

metabolism in familial type III dysbetalipoproteinaemia Eur J Clin Invest 1985, 15: 100-112.

5. Hazzard, W.R. \& Bierman, E.L. Aggravation of broad- $\beta$ disease (type 3 hyperlipoproteinaemia) by hypothyroidism. Arch Intern Med 1972, 130: 822-828.

6. Jacobs, D.R., Krieger, D.T. \& Charles, R.N. Late appearance of hyperlipemia in hypopituitarism. Ann Intern Med 1961, 55: 640-646.

7. Summers, V.K., Hipkin, L.J. \& Davis, J.C. Serum lipids in diseases of the pituitary. Metabolism 1967, 16: 1106-1113.

8. Ishibashi, S., Murase, T., Yamada, N., Tanaka, K., Takaku, F. \& Sato, K. Hyperlipidaemia in patients with hypopituitarism. Acta Endocrinol 1985, 110: 456-460. 